\title{
Distribution, Behavioral Ecology and Present Status of Varanus flavescens (a literature review paper) in Nepal
}

\author{
Ajay Karki ${ }^{1}$, Rabindra Bista ${ }^{2}$ \\ \& Santosh Humagain ${ }^{3}$
}

\begin{abstract}
Golden monitor lizard is a reptilian with long slender body, long neck, flexible head movable in all directions, feature that is not possessed by any other reptile. It is protected on international scale; listed in CITES appendix 1, the IUCN red data list, and categorized as protected reptile under national park and wildlife conservation act of Nepal. Even if distribution is wide it is threatened to extinction in much of its inhabitant range because of habitat destruction along with hunting for its hides, exploited for food and skin values. Exported illegally through northern Nepal to china as its skin is used in traditional Chinese medicine. To maintain their number as of this circumstances; habitat conservation and civic consciousness from stakeholders in integrated mode to minimize hunting, possibly will be the plausible way. This carnivore reptile is oviparous can grow up to $90 \mathrm{~cm}$ in length and tail measures about 49 $\mathrm{cm}$. Becomes sometimes dangerous, if threatened, rises high on its legs, hisses loudly, sways its body and lashes its razor like sharp tail and ready to cut offender and defend itself. So this paper reveals with distribution, ecological behavior and present status on Golden Monitor Lizard in Nepal.
\end{abstract}

Key Words: Protected, Threatened, Oviparous, Carnivorous, Medicine, Juveniles

\section{Introduction, Distribution and Identification}

Scientific classification

\begin{tabular}{|l|l|}
\hline Kingdom & Animalia \\
\hline Phylum & Chordata \\
\hline Class & Sauropsida \\
\hline Order & Squamata \\
\hline Suborder & Scleroglossa \\
\hline Infraorder & Anguimorpha \\
\hline Family & Varanidae \\
\hline Genus & Varanus \\
\hline Species & flavescens \\
\hline
\end{tabular}

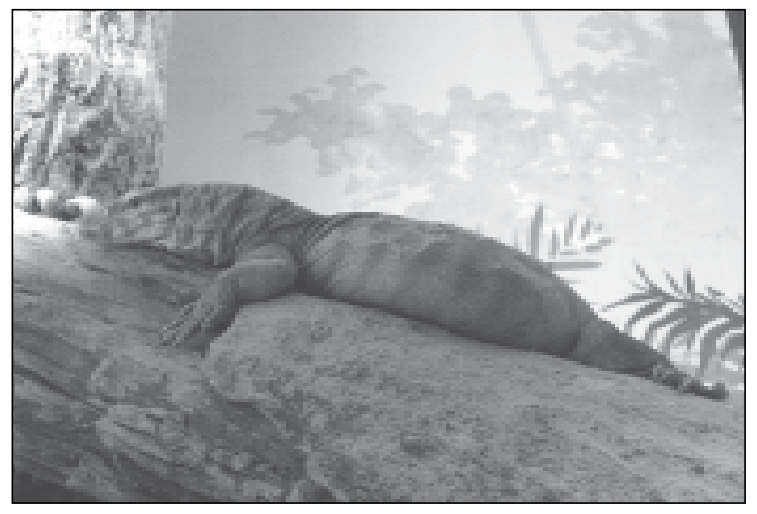

Source: www.commons.wikimedia

Kathmandu Forestry College, Kathmandu, Nepal, iofjay@yahoo.com

Kathmandu Forestry College, Kathmandu, Nepal, rabindrabista323@hotmail.com

Kathmandu Forestry College, Kathmandu, Nepal, santosh_humagain@yahoo.com 


\section{Introduction}

In 1973, the then His Majesty's Government of Nepal (HMG/N) developed a list of threatened wildlife species based on the surveys and research conducted in different areas of Nepal. The National Parks and Wildlife Conservation Act (NPWCA) contains 34 sections that provide a broad framework for establishing protected areas and conserving wildlife species in Nepal. This Act enforces the protection of 26 species of mammal, 9 species of bird and 3 species of reptile under schedule. Among them golden monitor lizard commonly named as yellow monitor, golden monitor, short toed monitor, Indian yellow monitor, Soon gohoro, Rani Gohoro, Pirro gohati, Ghoti, Godo is one of the most imperative species. This is an interesting lizard with long slender body mobile head and a long neck. The head is very flexible and can be moved in all directions, a feature not possessed by any other reptile. They are accustomed to take carrion also the contrasting coloration in juveniles stage than in adults and is mostly characterized by 11 dark transverse bars on the dorsal side. It is yellow in color with reddish brown and dirty yellow transverse bars. Generally juveniles are brightly colored and short with distinct spot and bars.

\section{Distribution}

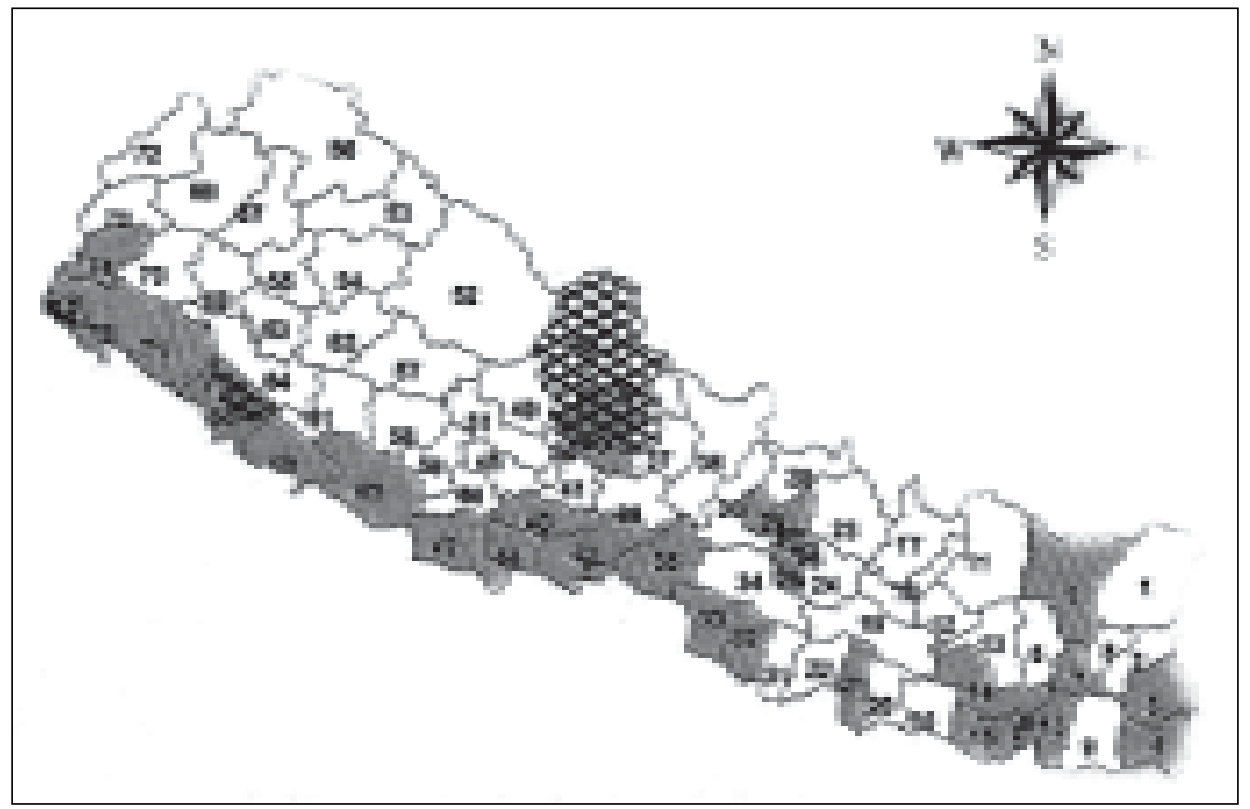

Source: IUCN, 2004, Herpetofauna of Nepal

This species is found widely in south Asian countries as in Nepal, India, Pakistan, Bangladesh and Burma. In Nepal, it is found habitually in bank of Gandaki, Koshi, Karnali and Mahakali rivers. Chitwan and Bardia National Parks are the core regions and occasionally seen in 25 districts of Nepal as shown in map and from time to time seen in the patches of Annapurna conservation area. (Shah and Tiwari, 2004). The species has been exterminated in large areas of its former range and occurs in isolated populations. 


\section{Morphology}

It grows up to $90 \mathrm{~cm}$ in length which is less than twice its height. Its tail measures about $49 \mathrm{~cm}$ and strongly compressed with a low double toothed crest above. Teeth acute feebly compressed. Snout short convex canthus nostrils distinct with an oblique slit a little nearer to the tip of the snout than to the orbit. Scales on the crown of the head smaller than the nuchal scales like the dorsal scales and are strongly keeled; median supraocular slightly enlarged transversely, abdominal scales smooth in 65-75 transverse rows. Their limbs are very well developed and armed with sharp, curved claws. The tongue is very long, slender and forked as that of snake. Its flicking tongue has odor receptors which helps monitor to locate it's pray. The eyes are very bulbous giving the monitor an alert appearance. The ear opening is distinct. The head is relatively short, high and covered with tiny scales and the body with minute tiled scales and tubercles above and smooth with suquarish shields below.

Digesting captive specimens remain inactive for several days. Monitor sometimes sleep for several days and sometimes for long hours in the water basin, (Schleicher and Kastle 2002). Fat reserves are stored in the body cavity as abdominal fat reserves and also along the tail base. Exceptionally they can comprise $13.8 \%$ the total weight.

\section{Feeding Ecology}

This carnivorous is fond of eggs but also preys on a wide variety of small animals; eats frogs, toads, fish, crabs, rats and even rotten flesh. Captive juveniles are fed twice a week whereas adults are fed once a week. One meal for a large monitor comprises 20 chicks or mice or 2 rats or 4-5 herrings. They explore the prey by smell and sight. They are adept at breaking open swallowed eggs and allowing the discharge of the juicy matter smoothly down the throat. The long, sharp and recurved teeth of a monitor are utilized for gripping not for chewing as with other animals. The monitor have to shallow prey whole, sometimes alive. They prey upon rats or birds by tearing them apart into pieces with teeth and claws and are then eaten.

\section{Predators}

I. Reptiles-Python molurus (adults), Naja naja (adults), Ophiophagus hannah (adults), Bungarus caeruleus (juveniles)

II. Birds-"Raptors"(juveniles), Spilornis cheela (adults), Haliaster indus (juveniles)

III. Mammals- Viverra zibethica (juvenile), Herpestes edwardsi (eggs), Felis domesticus (cat: juveniles), Felis chaus (Jungle cat: juveniles), Canis familiaris (Domestic dog: eggs), Canis aurous (jackal: juveniles), Vulpes bengalensis (Bengal fox: juveniles), Sus scrofa (Domestic pig: eggs)

IV. Man- including eggs for predation

\section{Parasites}

Prozonas (Flagellates, Amoebas, Sporozoa, Haemogregarina), Flatworms (platyhelminthes, tapeworms); Roundworms (Aschelminthes), Tongue worms (Linguatulida) are endoparasites; similarly Ticks (Ixodidae) is the ectoparasite. 


\section{Reproduction Ecology}

Male with prominent cloacae flaps. Oviparous, mating in June and July. Sexual maturity reaches in 2.5-3 yrs.

The male must immobile the female for mating therefore larger males with brachial strength have greater chances. Mounting dorsal embrace and chin rubbing against female's neck is the rotting behavior of an adult male. Head twitching by female is possibly a rejection signal; rejecting females climb into trees, on boulders, enter thickets or burrows or retreat into water.

As it is oviparous female lays an annual clutch of 6-30 eggs and are deposited in holes, burrows, termite mounds or in rotten logs. The size of eggs is $(45-60) *(26-32) \mathrm{mm}$, with average weight of $15.8 \mathrm{gm}$.

\section{Incubation, Hatching and Hatchlings}

Hatching of eggs at the temp of $29-30^{\circ} \mathrm{C}$ takes place in $235-254$ days, in $172-173$ days at $30-$ $34^{\circ} \mathrm{c}$. Females are reported to return egg sites. The juveniles are very secretive and are known as bib-cobras in terai, (Nepal and India) although lacks venom apparatus.

Juveniles stay together for several months living mainly in trees and feed exclusively on small invertebrates. Total length of $175(80+95) \mathrm{mm}$ color pattern is dark orange to brown with striking transverse bands of yellow and black over the body and tail. Juveniles grow rapidly, doubling their length in less than 2 yrs.

\section{Ecology and General Behavior}

\section{Habitat}

Prefers lowland marshes and swamps around water bodies, cultivated lands, rarer in mixed evergreen, secondary Sal forest, along the floodplains of large rivers, sometimes along in foothills but never in mountain areas. Often their habitats are sandy, but they avoid salty sand along coast. During the monsoon rains, the habitat is often inundated; they spend much time in the water. During the intense drought, they seek shelter in the cracks of drying marsh soil which reach down to one meter below the surface. They hide in burrows in banks around pools, lakes and canals as well as in cervices, drain holes, or termite mounds. The entrance is occasionally closed with earth. Climate change; present crucial issue may be another cause in attenuation their habitat and diminishing population; which is to be examined.

\section{Activity Pattern}

They are most active during the monsoon season when their habitat is flooded but conspicuous to observers during bright and rainless days. During the reproductive season, the male becomes especially active and are observed more than females. Captive were observed to be active for only half an hour in the morning and for the same time in the afternoon .They hibernate in regions with low winter temperatures and low precipitation from Nov -Feb., they like to bask 
at very high temperature $\left(45^{\circ} \mathrm{C}\right)$. They are good swimmer, like to rest partially submerged but are poor climbers as their toes are relatively short. They like to dig themselves into soft ground.

\section{Survival Ecology}

They become sometimes dangerous, if concerned and prevented from escaping, a monitor rises high on its legs, hisses loudly, sways its body and lashes its razor like sharp tail in ready to cut offender and defend itself. Besides giving severe blows with its muscular tail, a monitor can also bite. Escapes when possible; normal fleeing distance $2-15 \mathrm{~m}$, although in dense vegetation only $2 \mathrm{~m}$. Large specimens jump from trees and flee on the ground; small specimens ascend trees and hide there under bark, in cervices or dense foliage. The tail arch dorsally flatten laterally, produce gular pouch, hiss, gape, lash with the tail, lunge, rarely bite, but may take a firm hold and tear deep and severe wounds.

\section{Present Status}

This has become threatened with extinction in its range. Its former habitats, the plains along rivers have largely been cultivated. This is protected on international scale, listed in CITES appendix-1, the IUCN red data list, and categorized as protected reptile under national park and wildlife conservation act of Nepal. But the status, number, habitat and behavioral ecology is not known till now.

\section{Economic Importance}

The species was and is still hunted for its hides. Nepal exported 849 monitor (not defined species) hides in 1969 (Schleich HH and Kastle W 2002). The higher quality skins are used for handbags and the others for belts and watchstraps. The price of hide was $\$ 1.60$ in 1987(Schleich and Kastle 2002). Highly exploited for its food and skins. Exported illegally from Nepal to china since its skin is used in traditional Chinese medicine. Hunting on a local scale and smuggling is still tolerated by the local authorities. The monitors are skinned and the rest, including most of the skeleton is boiled until it becomes soft and then consumed.

The skin of the monitor lizard is used in making some musical instruments, the fat and the oil extracted from the visceral organ is used as a constituent of an embrocation that is used for the treatment of arthritis and some other ailments of aged people.

\section{The Way Forward}

Even though the species has a wider distribution in Nepal but because of its habitat destruction very rapidly, it has been categorized as protected species under the national park and wildlife conservation act 1973 and listed in CITES appendix 1 and in the IUCN red data list. Illegal hunting for its skin, food, medicine and used in either domestic level or exported which in due course has resulted in thrashing of population, and therefore the species is considered under threat to extinction. To get them out of these circumstances, habitat conservation and civic consciousness to minimize hunting could be possibly the plausible way. Although many researches are being carried out in mammals especially in mega animals; not a single study is 
done to date on this species from conservation point of view. So efforts from all concerned stakeholders(may be central zoo, National trust for nature conservation,Tribhuwan university along with its different institutes, department of national park and wildlife conservation) in integrated way is urgent and need of the hour to conserve them. To show Nepal as the habitat of Golden monitor lizard for future generation we should start conservation from this moment.

\section{References:}

Anderson J, 1871 on Some Indian Reptile's Proc.Zool.Soc.London

Chapagain D and Dhakal J; 2001. ISBN: 99933-204-1-2; P 95, Nepalma CITES Karyanwyan, Parichaya ra Pahichan Pustika

Gulati N.K. 1981.A Glossary of Forestry Terms

Kotpal R.L., 1998. ISBN: 81-7133-367-2; P230; Modern Textbook of Zoology

Mahendra, B.C. 1983.Hand Book of Snakes of India, Ceylon, Burma, Bangladesh and Pakistan. The Academy of Zoology, Agra, India.

Schleich H.H. and Kastle W 2002. ISBN: 3-904144-79-0(Germany), P 779, Amphibians and Reptiles of Nepal

Shah K.B. and Tiwari S, 2004. ISBN: 99933-860-3-0, P-141: Herpetofauna of Nepal, a Conservation Companion

Shrestha T. K, 2001. Herpetology of Nepal, A Field Guide to Amphibians and Reptiles of Trans Himalayan Region of Asia

www.centralpets.com/pages

www.commons.wikimedia.org/wiki

www.forestryimages.org

www.nepalvista.com/features/nepal-parks

www.oklandzoo.org/meet_the_animals

\section{प्रगतिको आधार सेवासँग कारोवार !!!}

\section{विजयादशमी तथा शुभ-दिपावली २०६ू को पावन उपलक्ष्यमा समस्त ग्राहकवर्ग,} शेयरधनी महानुभाव एवं शुभचिन्तकहरम्मा हार्दिक मंगलमय

शुभ-कामना।

सेवा का सेवाहरु:

$\checkmark$ सस्तो एवं सर्वसुलभ व्याजमा कर्जा प्रवाह ।

$\checkmark$ उच्च प्रतिफल सहितको निक्षेप योजना।

$\checkmark$ रेमिटान्स साथै वैंक ग्यारेन्टीको सुविधा।
सेवा विकास बैक लि. Sewa Bikash Bank Ltd. बुटवल-५, पुष्पलाल पार्क

फोन नं.: ०७१-४४६६९९३, ५ ४६९९૪ फ्याक्स नं.: प४२६९४

E-mail: sbbl@wlink.com.np 